\title{
Catfish (Teleostei: Siluriformes) diversity in Karala River of Jalpaiguri District, West Bengal, India
}

\author{
Amal Kumar Patra \\ Department of Zoology, Ananda Chandra College, Jalpaiguri, West Bengal 735101, India \\ Email: amalpatra@yahoo.co.in
}

\begin{abstract}
The diversity of fresh water catfish fauna of the Karala River in Jalpaiguri District of West Bengal was studied from February 2009 to January 2010. A total of seven species belonging to six genera and six families were identified. Bagridae was the dominant family with two representatives, whereas Amblycepitidae, Chacidae, Olyridae, Sisoridae and Siluridae were each represented by single species. Maximum fish diversity was recorded higher in Hakim Para $\left(\mathrm{H}^{\prime}=1.266\right)$ as compared with DasPara $\left(H^{\prime}=1.218\right)$ and Aquiduct $\left(H^{\prime}=1.04\right)$. The evenness index at three sampling stations indicates uneven distribution of catfish in this tributary, possibly due to the irregular depth of river, occurrence of submerged vegetation and physicochemical water characteristics.
\end{abstract}

Keywords: Bagridae, Catfish, Karala River, Siluriformes fishes.

The major riverine fishery resources of northern West Bengal are provided by the Teesta, Torsha, Jaldhaka, Mahananda, Raidak, Sankosh, Kaljani, Korotoa, Punarbhaba and Atrai river systems. The Teesta originates from Jemu glacier in Sikkim and

Date of publication (online): 26 March 2011

Date of publication (print): 26 March 2011

ISSN 0974-7907 (online) | 0974-7893 (print)

Editor: W. Vishwanath

\section{Manuscript details:}

Ms \# 02474

Received 30 May 2010

Final received 20 January 2011

Finally accepted 04 February 2011

Citation: Patra, A.K. (2011). Catfish (Teleostei: Siluriformes) diversity in Karala River of Jalpaiguri District, West Bengal, India. Journal of Threatened Taxa 3(3): 1610-1614.

Copyright: (c) Amal Kumar Patra 2011. Creative Commons Attribution 3.0 Unported License. JoTT allows unrestricted use of this article in any medium for non-profit purposes, reproduction and distribution by providing adequate credit to the authors and the source of publication.

Acknowledgements: I am grateful to University Grant Commission (UGC) for providing research grant; to the Principal, Ananda Chandra College for providing me research laboratory of zoology department and others administrative help; to the Director, Zoological Survey of India, Kolkata for giving me an opportunity to take short course training on fresh water fish identification under the supervision of Dr. A.K. Karmakar, Dr. S. Kar and Dr. S.S. Mishra; to my colleagues (Dr. Tanmay Datta and Santanu Ghosh Dastidar) for giving me valuable suggestions different times during this study.

OPEN ACCESS | FREE DOWNLOAD is the largest river of northern West Bengal, passing through the districts of Darjeeling, Jalpaiguri and Mekhliganj subdivision of Coochbehar and meeting the Brahmaputra (known as Yamuna in Bangladesh). The main stream is connected by several tributaries including the Karala (also known as Kalla), which originates from the Baikunthapur forest and flows down into the Teesta near Mandal Ghat in Jalpaiguri Town, bisecting Jalpaiguri District (located on the confluence of river Teesta and Karala). The total catchment area is $141 \mathrm{~km}^{2}$, most of which is covered by arable land. The basin of this river sustains life and livelihoods of tea gardeners, fishermen and slum-dwellers.

So far as ichthyofauna diversity in northern Bengal is concerned, the earliest report is by Shaw \& Shebbeare (1937), who reported 131 species from the rivers, streams and ponds in the hills and plains of the Darjeeling District and the adjoining Duars. Of these 131 species they reported 34 species of catfish. Hora \& Gupta (1941) reported on a small collection of fish from Kalimpong, Duars and Tarai, adding two species to this list. In 1977 Jayaram \& Singh reported 26 species of catfish from the TenganMahananda confluence, the Atrai, Purnabhasa, Dharla (at Changrabandha), Kalindri, Mahananda (at Malda Town), Jamuna (at Hilli Village of Balurghat), Teesta, Karotayar, Panga, Balasan and Jaldhaka. None of these sites were connected with the Karala River, thus the present study represents the first attempt to study ichthyofauna diversity in this lotic system and determine fresh water catfish resources, distribution, diversity and status on the basis of catch frequency.

\section{Materials and Methods}

Fortnightly fishes were captured from three different study sites (Fig. 1) of the Karala River. Station-I (Aquiduct) is located near the origin of the river at $26^{\circ} 47^{\prime} 13^{\prime} \mathrm{N} \& 88^{\circ} 32^{\prime} 17^{\prime}$ 'E, $122 \mathrm{~m}$ elevation. From Jalpaiguri town its distance by bus route is $32 \mathrm{~km}$, water 


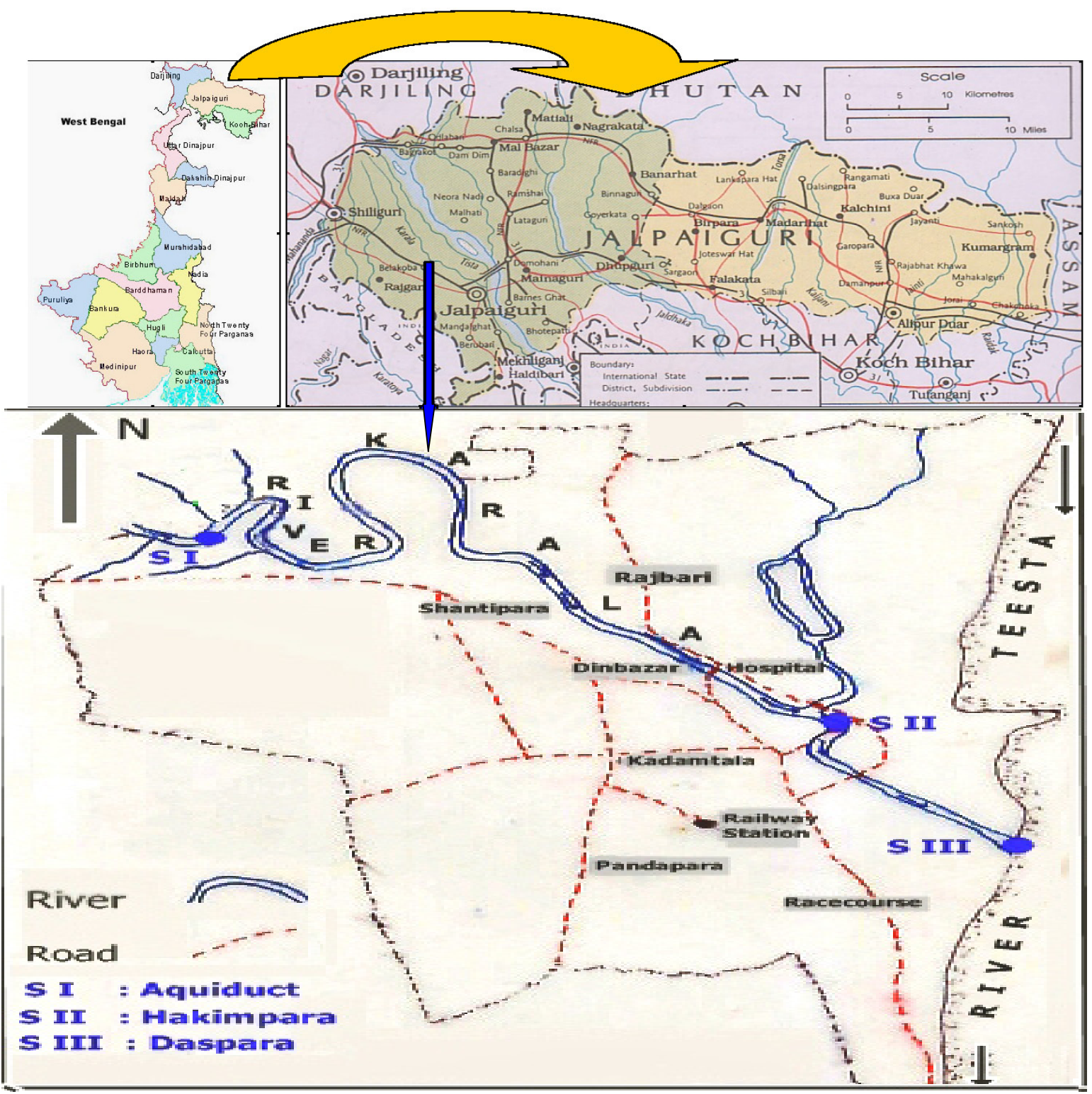

Figure 1. Origin and distribution of Karala River with three different study sites

depth is 0.4 to $0.6 \mathrm{~m}$ pre-and-post monsoon, rising during rain and flood 4 to $5.5 \mathrm{~m}$. At station-I fish were captured by cast net (mesh size $6 \times 6 \mathrm{~mm}$ ) and naphi jal (local contrivance, mesh size $5 \times 5 \mathrm{~mm}$ ). Station-II is located in the heart of the district town and behind the hospital and market (Hakim Para) at 26031'51'N \& 88 43 '23"E, 86m elevation. From Jalpaiguri District town its distance by bus route is $0.5 \mathrm{~km}$, regular water depth is 3.7 to $5.2 \mathrm{~m}$ during pre-and-post monsoon, during rain fall and flood the depth increase to 6.6 to $7.6 \mathrm{~m}$. Station-III is located at the junction of Teesta and Karala near Daspara at $26^{\circ} 28^{\prime} 42^{\prime \prime} \mathrm{N}$ \& $88^{\circ} 44^{\prime} 27^{\prime \prime} \mathrm{E}, 81 \mathrm{~m}$ elevation. From Jalpaiguri district town its distance by bus route is $7 \mathrm{~km}$, regular water depth is 3.7 to $4.6 \mathrm{~m}$ during pre- and post-monsoon and during rain fall and flood it increases to 6.1 to $7 \mathrm{~m}$. In station II and III fishes were captured by vessel net or khara jal (local contrivance, mesh size $6 \times 6 \mathrm{~mm}$ ), gill net (variable mesh sizes), and cast net ( $5 \times 5 \mathrm{~mm}$ mesh size). Colour, colour patterns, spots etc. were noted immediately after capture and photographs were taken by Nikon Coolpix S4, fishes were killed by formalin solution containing one part commercial formalin (37$40 \% \mathrm{HCHO})+$ nine part glass distilled water and $7 \mathrm{~g}$ Borax/liter (Jayaram 1981). All samples were kept in this buffer formalin solution for 4-5 hours for proper 
Table 1. Species diversity of cat fishes and their local name, status and fishery importance.

\begin{tabular}{|c|c|c|c|c|c|}
\hline & Scientific Name & English Name & Local Name & $\begin{array}{l}\text { Status (According to catch } \\
\text { frequency) }\end{array}$ & $\begin{array}{l}\text { Threat status } \\
\text { (Barman 2007) }\end{array}$ \\
\hline 1 & $\begin{array}{l}\text { Bagridae } \\
\text { Mystus bleekeri (Day) }\end{array}$ & Day's Mystus & $\begin{array}{l}\text { Golsha Tengra or } \\
\text { Palwa Tangra }\end{array}$ & Rare in S-II and S-III & Vulnerable \\
\hline 2 & $\begin{array}{l}\text { Bagridae } \\
\text { Mystus tengara (Hamilton) }\end{array}$ & Tengara Mystus & $\begin{array}{l}\text { Halud or Kalo } \\
\text { Tengra }\end{array}$ & Common in both S-II and S-III. & Out of danger \\
\hline 3 & $\begin{array}{l}\text { Amblycipitidae } \\
\text { Amblyceps mangois (Hamilton) }\end{array}$ & Indian Torrent Catfish & Ban Magoor & $\begin{array}{l}\text { Common in S-I during entire } \\
\text { study. }\end{array}$ & Near Threatened \\
\hline 4 & $\begin{array}{l}\text { Chacidae } \\
\text { Chaca chaca (Hamilton) }\end{array}$ & Squarehead Catfish & $\begin{array}{l}\text { Chaga or Chag- } \\
\text { bega. }\end{array}$ & Common in S-II and S-III. & Out of danger \\
\hline 5 & $\begin{array}{l}\text { Olyridae } \\
\text { Olyra longicaudata McClelland }\end{array}$ & Longtail Catfish & $\begin{array}{l}\text { Bot Singhi, } \\
\text { Ranghang. }\end{array}$ & Abundant in S-I. & Out of danger \\
\hline 6 & $\begin{array}{l}\text { Siluridae } \\
\text { Wallago attu (Bloch \& Schneider) }\end{array}$ & $\begin{array}{l}\text { Wallago or Fresh } \\
\text { Water Shark }\end{array}$ & Bowal & Occasional in S-II and S-III & Near Threatened \\
\hline 7 & $\begin{array}{l}\text { Sisoridae } \\
\text { Erethistoides montana montana Hora }\end{array}$ & Nil & $\begin{array}{l}\text { Kutakanti' or } \\
\text { Kurkati. }\end{array}$ & Common in S-I. & Out of danger \\
\hline
\end{tabular}

fixation. Catfish were segregated from the master stock and subsequently identified by the literature of Jayaram $(1999,2006)$ and Talwar \& Jhingran (1991). Scientific names were confirmed from freshwater fish section of ZSI, Kolkata.

The frequency of occurrence of each species was calculated based on the number of occasions the species was collected during the samplings. The status was determined with the help of a standard catch frequency chart presented by Tamang et al. 2007 (Catch frequency 91-100 \% = Common, 81-90 $=$ Abundant, $61-80=$ Frequent, $31-59=$ Occasional, 15-30 = Sporadic, 05-14= Rare and $<5 \%=$ Extremely rare). Threat status and endemism were assigned following Barman (2007). The diversity and evenness indices were calculated according to Shannon-Weaner (1949) and Pielou (1975). Capture of fish was done from 0800 to $1300 \mathrm{hr}$ each sampling day. The study was carried out from February 2009 to January 2010.

\section{Results}

A total of seven species belonging to six families and six genera were collected. They have naked skin or bony scute or plates, scales are always absent. Their oral portion contains nearly always $1-4$ pairs of barbells. The atlas, axis, $3^{\text {rd }}$ and $4^{\text {th }}$ vertebrae are ossified and form a complex vertebra. An analysis of the taxonomic composition of the catfish fauna suggests Bagridae to be the most dominant family with two representatives occurring at SII and SIII. Amblycepitidae, Chacidae, Olyridae, Sisoridae and Siluridae each had a single species representation.
A check list of captured fish, local names, status (on the basis of catch frequency) and threat status is presented in Table 1. On the basis of catch frequency Amblyceps mangois (Image 1) and Erethistoides montana montana (Image 2) were common, and Olyra longicaudata (Image 3) was abundant at upstream (SI). They were extremely rare at SII and not captured at SIII. This observation indicates that the above three catfishes are hill stream fish representatives and prefer low current and least water depth. The Mystus tengara (Image 4) and Chaca chaca (Image 5) are common,

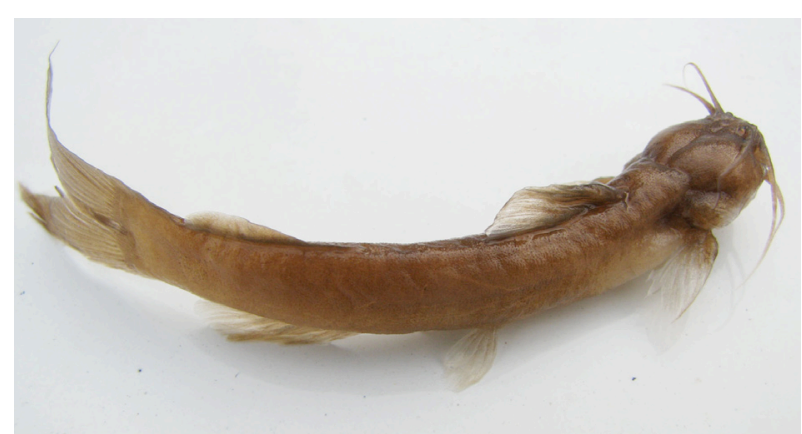

Image 1. Amblyceps mangois (Hamilton)

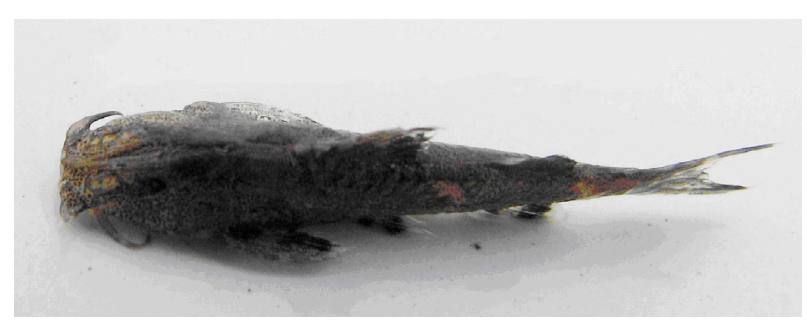

Image 2. Erethistoides montana montana Hora 


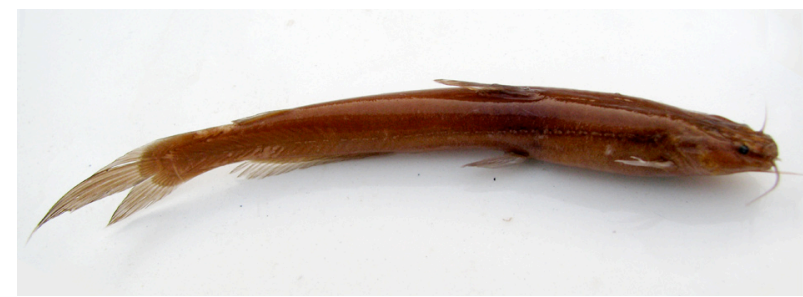

Image 3. Olyra longicaudata McClelland

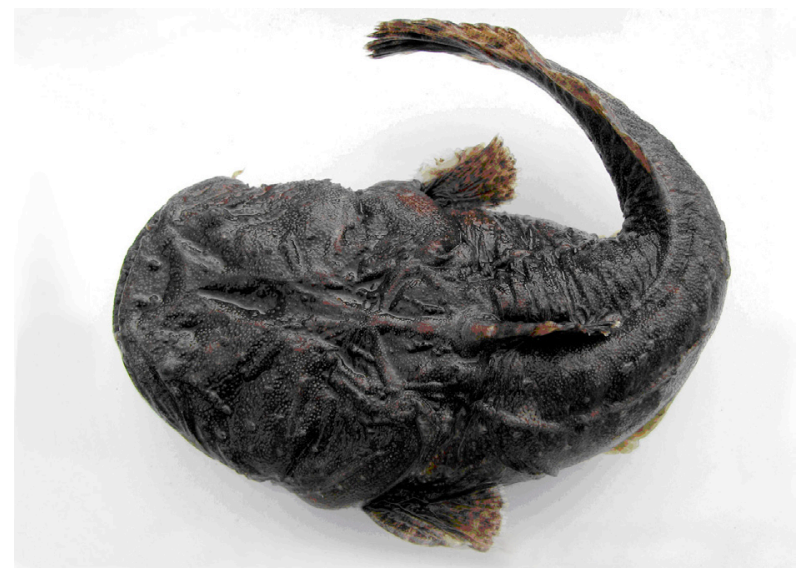

Image 5. Chaca chaca (Hamilton)

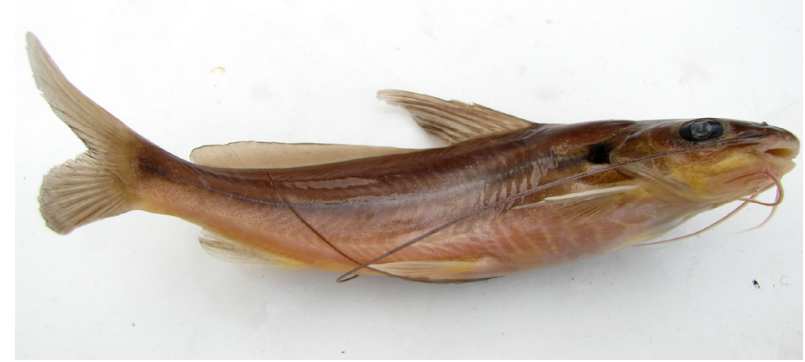

Image 7. Mystus bleekeri (Day)

Wallago attu (Image 6) was occasional and Mystus bleekeri (Image 7) was rare in both SII and SIII. The species richness in three sampling sites of this river showed considerable variation and higher richness was recorded in the mid to down stream. Maximum species richness was recorded from SII (Hakimpara, total number $=06)$ and SIII (Daspara, total species $=$ 04) while lower species richness was recorded from SI (Aquiduct, total number $=03$ ) respectively. The species diversity index of different sampling sites was ranged from 1.04 to 1.218 . In this study maximum fish diversity was recorded higher in SII $\left(\mathrm{H}^{\prime}=1.266\right)$ as compared with SIII $\left(\mathrm{H}^{\prime}=1.218\right)$ and SI $\left(\mathrm{H}^{\prime}=1.04\right)$

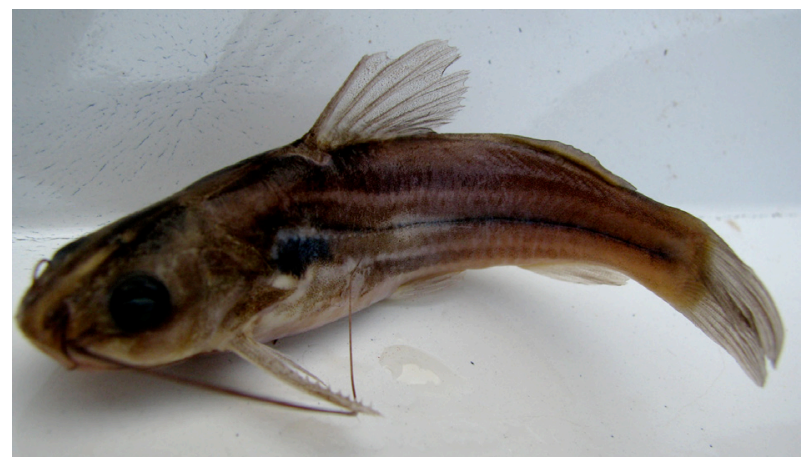

Image 4. Mystus tengara (Hamilton)

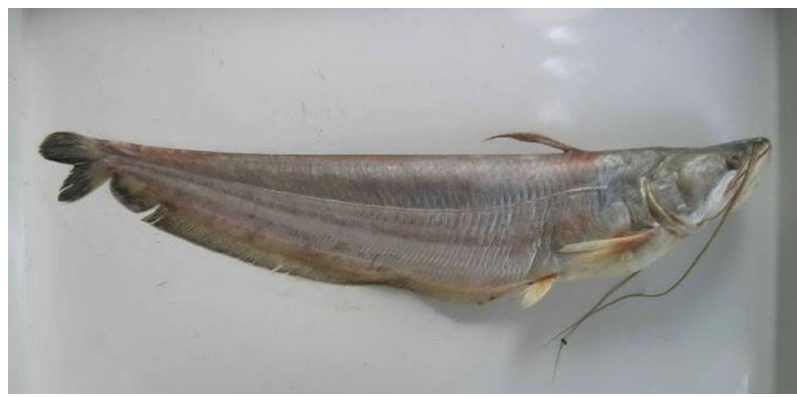

Image 6. Wallago attu (Bloch \& Schneider)

and indicates good correlation with over all species richness across the sites. The evenness index at three sapling stations $(\mathrm{SI}=0.947, \mathrm{SII}=0.707$ and $\mathrm{SIII}=$ 0.879 ) indicates uneven distribution of catfishes in this tributary.

\section{Discussion and Conclusions}

The knowledge of ichthyofaunal diversity, their present threat status, role in ecosystem and human economy are prerequisites for adopting the proper conservation strategies of fish fauna. The present study has recorded seven species of catfishes from Karala River, a tributary of the river Teesta. In this lotic system they were distributed unevenly, down streams were richest and more diversified than upstream. At down streams, the highest organic load occurs that cause the productivity. Sub-merged weeds of SII (Hakim Para) and SIII (Daspara) provide the shelter and food of fishes. For these reasons the diversity is high. It also may be due to the heterogeneous depth of water body due to silting, abundance of prey, substratum soil quality and physico-chemical features of water like temperature, $\mathrm{pH}$, turbidity, total solid, dissolved oxygen, BOD etc. Three species are threatened catfishes of India found 
in this river (Table 1). Among these three species, one has been designated as Vulnerable and two have been designated as Near Threatened by Barman (2007). The rest are data deficient or out of danger. The only species Erethistoides montana montana Hora is endemic to northern Bengal (Barman 2007). The cause of threatening may be due to the habitat loss, habitat degradation, over exploitation, pollution and unscientific capture technology.

Till date it is unfortunate that the Karala River of Jalpaiguri District has not received any attention from the ichthyological aspects. This report gains importance as the Karala River has been described as one of the most important tributaries of Teesta.

\section{REFERENCES}

Barman, R.P. (2007). A review of the fresh water fish fauna of West Bengal, India with suggestions for conservation of the threatened and endemic species, Records of the Zoological Survey of India, Occasional Paper 263: 1-48.

Hora, S.L. \& J.C.Gupta (1941). On a collection of fish from Kalimpong, Duars and Siliguri Terai, North Bengal. Journal of Asiatic Society of Bengal 47: 183-202.

Jayaram, K.C. \& K.P. Singh (1977). On the collection of fish from North Bengal. Records of Zoological Survey of India 72(1-4): 243-275.
Jayaram, K.C. (1981). Methods of preservation of fishes, p. 5. In: Director, ZSI (ed.). The Fresh Water Fishes of India, Pakistan, Bangladesh, Burma and Srilanka - A Handbook. Calcutta Laser Graphics (P) Ltd., Calcutta, iii $+475 \mathrm{pp}+13 \mathrm{pls}$.

Jayaram, K.C. (1999). Systematic account of Siluriformes fishes, pp. 220-318. In: The Fresh Water Fishes of the Indian Region. Narendra Publishing House, New Delhi, $\mathrm{v}^{+}$ $551 \mathrm{pp}+18 \mathrm{pls}$.

Jayaram, K.C. (2006). Catfishes of India. Narendra Publishing House, New Delhi, xxii $+383+11$ pls.

Pielou, E.C. (1975). Ecological Diversity. John Wiley and Sons, New York, NY, 165p.

Shannon, C.E. \& W. Weaner (1949). The Mathematical Theory of Communication. University of Illinois Press, Urbana, 163p.

Shaw, G.E. \& E.O. Shebbeare (1937). The fishes of North Bengal. Journal of the Royal Asiatic Society of Bengal (Science) 3(1): 1-137.

Talwar, P.K. \& A.G. Jhingran (1991). Systematic account of Siluriformes fishes, pp. 543-714. In: Inland Fishes of India and Adjacent Countries-Vol. 2. Oxford and IBH Publishing Copany, New Delhi, 1158pp.

Tamang, L., S. Chaudhry \& D. Choudhury (2007). Ichthyofaunal contribution to the state and comparison of habitat contiguity on taxonomic diversity in Senkhi stream, Arunachal Pradesh, India. Journal of the Bombay Natural History Society 104(2): 170-177. 